\title{
Biodiversity of honey bees (Apis mellifera L.) in Turkey by geometric morphometric analysis
}

\author{
Meral KEKEÇOĞLU *1,5 , Merve KAMBUR ACAR ${ }^{2}$, Songül BİR ${ }^{3}$, Tuğçe ÇAPRAZLI ${ }^{4}$, Münir UÇAK ${ }^{2,5}$ \\ ORCID: 0000-0002-2564-8343; 0000-0001- 9658-6584; 0000-0002-4116-4138; 0000-0001-9109-0969; 0000-0003-
} $1538-6711$

\author{
${ }^{1}$ Düzce University, Faculty of Science, Department of Biology, 81620 Düzce, Turkey \\ ${ }^{2}$ Düzce University, Düzce Vocational School, Beekeeping Program, 81620 Düzce, Turkey \\ ${ }^{3}$ Düzce University, Institute of Science, Department of Biology, 81620 Düzce, Turkey \\ ${ }^{4}$ Düzce University, Institute of Medical Sciences, Depart. of Natural, Herbal and Cosmetic Products, Düzce, Turkey \\ ${ }^{5}$ Düzce University, Beekeeping Research Development and Aplication Centre, 81620 Düzce, Turkey
}

\begin{abstract}
In this study, the honey bee diversity existing in Turkey were explained by geometric morphometric methods. For this purpose, the deviations of the junction points in the right wing veins were analyzed with the Draw Wing software program. Generalized Procrustes Analysis and Principal Component Analysis were performed to distinguish the populations according to the deviations in the intersections of the wing vein angles. In the first two canonical planes, honey bee populations were divided into two main groups, Southeastern Anatolia and others. While honey bees in Southeastern Anatolia, which differ in terms of shape morphology, formed a separate group in the UPGMA dendrogram, all the rest grouped closer with each other except Thrace region. This population was not separated from the others in the scatter graph but unseparated in the UPGMA dendrogram. The proximity of the Thracian honey bee population to other groups on the Plot supports that there may be a mixture in this region. Also, the fact that the Southeastern Anatolia population constitutes a separate group in both dendogram and scatter graph showed that there may be a different race in this region.
\end{abstract}

Key words: Apis mellifera L., Anatolia, biodiversity, forewing, TpsDig

Özet

\section{Geometrik morfometrik analiz ile Türkiye'deki bal arısı (Apis mellifera L.) biyoçeşitliliği}

Bu çalışmada, Türkiye'deki bal arısı çeşitliliğini geometrik morfometrik yöntemle açıklanmaya çalışılmıştır. $\mathrm{Bu}$ amaçla, sağ kanat damarlarındaki kesişim noktalarının sapmaları Draw Wing yazılım programı ile analiz edildi. Popülasyonları kanat damar açılarının kesişim yerlerindeki sapmalara göre ayırt etmek için Generalize Procrustes Analizi ve Temel Bileşen Analizi yapıldı. İlk iki kanonik düzlemde bal arısı popülasyonları Güneydoğu Anadolu ve diğerleri olmak üzere iki ana gruba ayrıldı. Şekil morfolojisi açısından farklılık gösteren Güneydoğu Anadolu'daki bal arıları UPGMA dendrogramında ayrı bir grup oluştururken, Trakya bölgesi dışında kalan populasyonların tamamı birbirine daha yakın bir grup oluşturmuştur. Trakya populasyonu UPGMA dendogramında ayrı bir grup oluşturur iken, saçılım grafiğinde diğer populasyonlardan belirgin olarak ayrılmamıştır. Trakya bal arısı popülasyonunun diğer gruplara yakınlığı bu bölgede bir karışımın olduğunu desteklemektedir. Aynı zamanda Güneydoğu Anadolu populasyonun hem dendogram hem de saçılım grafiğinde ayrı bir grup oluşturması bu bölgede farklı bir irk bulunduğuna işaret etmektedir.

Anahtar kelimeler: Apis mellifera L., Anadolu, biyoçeşitlilik, TpsDig, ön kanat

\section{Introduction}

Behavioral complexity, genetic diversity and morphologic distinction methods have been referenced methods on subspecific classification and phylogeographic inferences in Apis mellifera L. As a genetic tool, especially

\footnotetext{
* Corresponding author / Haberleşmeden sorumlu yazar: Tel.: +905326885280; Fax.: +905326885280; E-mail: meralkekecoglu @ duzce.edu.tr (c) Copyright 2020 by Biological Diversity and Conservation $\quad$ Received: 8.8.2020; $\quad$ Published: 15.12.2020 BioDiCon. 914-0820
} 
mitochondrial RFLP and sequence analysis are widespread techniques to explain current status of honey bee diversity. These attempts are generally share similar and correlative results of morphometric studies which are supported the 4 major dispersal lineages. However, as new information is acquired some controversies revealed about the composition and validity of branches $\mathrm{C}, \mathrm{O}$ and supporting new fourth mtDNA lineage. According to mtDNA analysis " $\mathrm{C}$ " lineage combines also "O" morphological lineages [1,2].

Southwest Asia, included Anatolia (Turkey), is a zone of high morphological diversification and evolution for honey bees. Honey bee races in this region, A. m. anatoliaca, A. m. caucasica, A. m. meda and A. m. syriaca were considered to form a basal branch "O" of the subspecies by researchers [3,4]. A. m. caucasica populations are spread throughout eastern Black Sea coast, A. m. meda in the southeastern region and A. m. syriaca in the extreme south, near the border with Syria. A. m. anatoliaca distribute throughout the rest of Anatolia and Thrace. Later, based on mtDNA, it was claimed that A. m. carnica have been in European part of Turkey, According to Ruttner's classification, $A$. $m$. carnica belongs to the branch " $C$ " $[5,6,7,8]$. In the last, Kandemir, et al., [9] reported the existence of fourth new mtDNA lineage "O" in the extreme South near the Syrian border of Turkey. mtDNA studies on Anatolian honey bees showed that A. m. anatoliaca and A. m. caucasica located the Eastern or " $C$ " mitochondrial lineage $[5,9,10]$ as do $A$. $m$. ligustica and A. m. carnica. These results differ from Ruttner's findings, that A. $m$. caucasica and A. m. anatoliaca were diverged in a separate oriental group of subspecies.

Based on mtDNA, it would be difficult to synthesize the results at the European scale. Morphometrical parameters are universal in contrast to having some difficulties related to interpretations and explanations with graphic and personal errors. Many of these problems on traditional morphometric methods, can be achieved by alternative geometric morphometrics model $[11,12,13,14,15]$. Cartesian coordinate data usually limited to landmark point locations on the geometric morphometric analysis being a powerful tool in evolutionary studies to explore intraspecific variation at the population level [16]. From this perspective; geometric morphometrics gain an advantage over traditional approaches include; (1) using Procrustes distance, to detect differentiation ranks of wing shapes, (2) defining the description of feature of the multidimensional shape space using distance coefficient, (3) advancement of distinctive statistical methods for descriptive shape analysis, and (4) the descriptive attitude for new techniques also the graphical representations of the results $[12,13,16,17,18]$. By using this approach in the previous studies, three honey bee subspecies (A. m. carnica, A. m. caucasica, A. m. mellifera) were well separated [19]. Genetic changes with Africanized honey bees were well identified by using landmark-based geometric morphometrics [11,15,20,21]. Also, this method was taken place on honey bee subspecies from mainland Grete and Ionian Islands to investigate the differentiation between honey bee population [22]. In the present study landmark-based geometric morphometric method was applied to investigate Turkish honey bee biodiversity in Anatolia. It was focused on the study was to determine morphometric variation of honey bees distributed in Turkey using geometric morphometric methods based on landmark and to explain this diversity with the previous morphometric analysis and mtDNA results.

\section{Materials and methods}

\subsection{Field study and sampling}

Field studies were performed in 30 locations belong to the seven regions of Turkey (Fig 1). Samples were collected from small managed apiaries which are non-migratory beekeeping and requeening of colonies. Five honey bee colonies were randomly chosen from per apiary, 20-25 colonies from per city, also each colony were represented by 10 worker bees. Preparations of samples for the microscope slides were performed according to method of Kekeçoğlu [14].

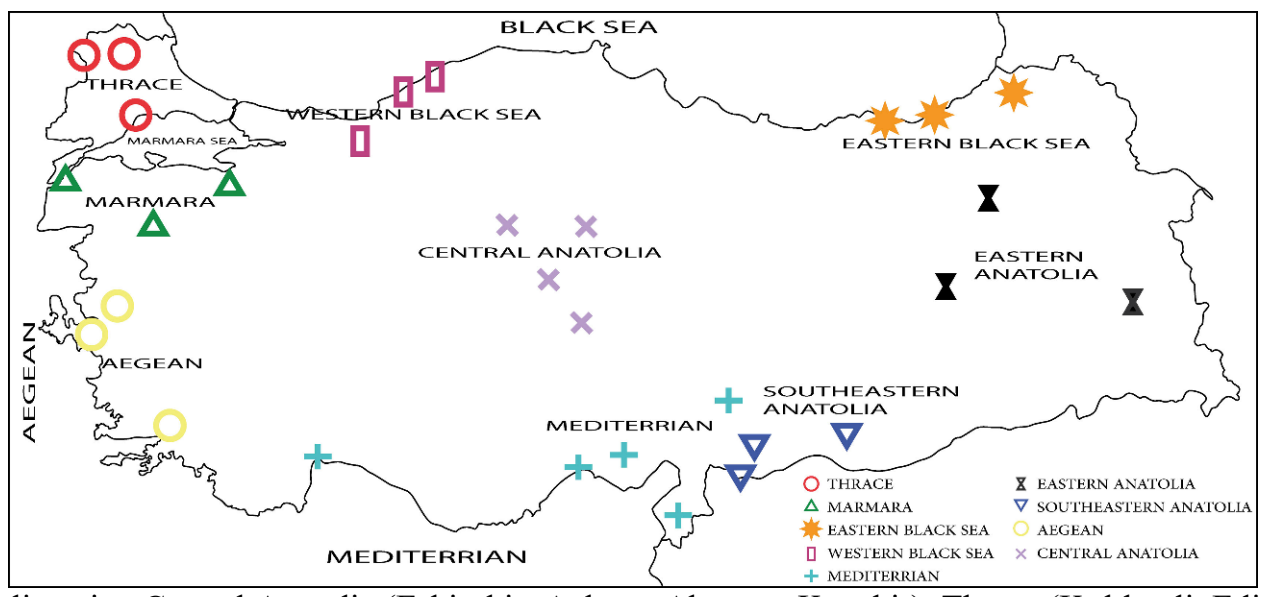

Figure 1. Sampling site; Central Anatolia (Eskişehir, Ankara, Aksaray, Kırşehir), Thrace (Kırklareli, Edirne, Tekirdağ), Easthern Black Sea (Artvin, Ardahan, Trabzon), Western Black Sea (Düzce, Bolu, Zonguldak), Marmara (Çanakkale, Balıkesir, Bursa), Aegean (Manisa, İzmir, Muğla), Mediterrian (Antalya, Mersin, Kahramanmaraş, Hatay, Adana), Southeastern Anatolia (Gaziantep, Kilis, Şanlıurfa), Easthern Anatolia (Bingöl, Van, Erzurum) 


\subsection{Data collection}

Using a Leica MZ-7.5 stereo microscope and 300 digital camera system wing slides were photographed. They were archived and labeled with unique codes. All slides were scored by responsible researcher. Photographs were first input to tps-UTIL1.28 [17]. Two dimensional Cartesian coordinates (2-D coordinates) of 18 landmarks from the right front wings (Fig 2) were digitized by tps-DIG1.40 [23]. Analogous systems were not used during this experiment to keep the digital errors in minimum.

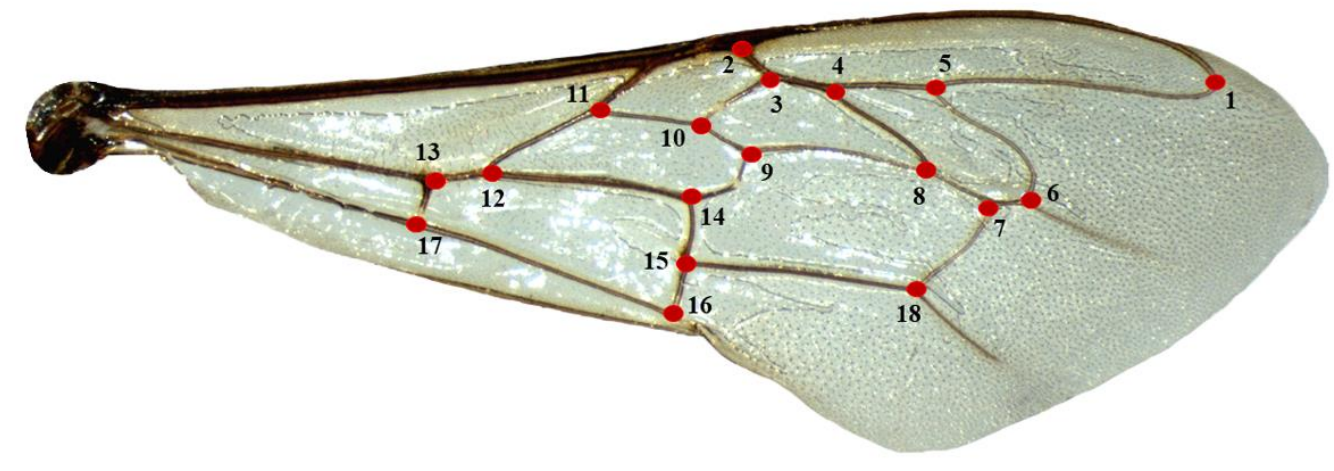

Figure 2. Location of the 18 landmarks on the schematic wing of a honey bee

\subsection{Statistical analysis}

Undeformed 6745 forewings were examined in analyses. Using tps-RELW1.34 [24] and Morpheus [25], all coordinates were examined and calculate eigenvalues for each principal warp. The landmark configurations were scaled, translated and rotated against the consensus configuration by Generalized Procrustes Analysis (GPA), formerly termed Generalize Least superimposition (GLS) method (Fig 3) [16,26,27]. The changeability in the shape space was evaluated using the scores provide for each figure on the first two relative warps on PCA these relative warps account for the principal components and define a shape space [27]. Mean front wing configurations of each population were visualized sensitively. Then, relative warps analysis was performed to per wings for the consensus configurations.

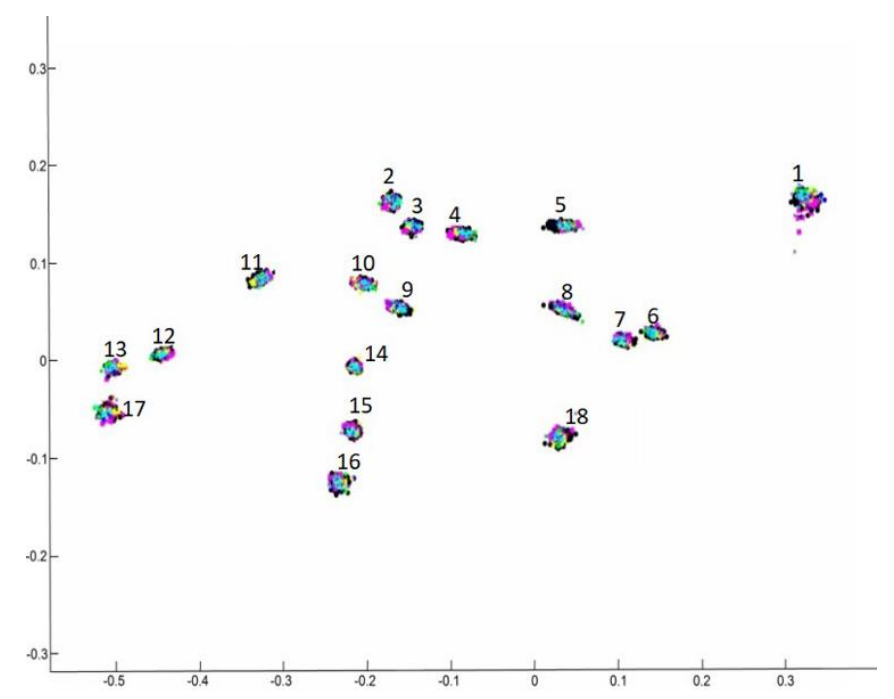

Figure 3. Generalize Least Superimposition (GLS) of landmarks

To calculate landmark procrustes distances, MANOVA and permutation tests were applied. Using the tpsRELW, wing deformations were showed on the first two axes of PCA graph [24]. Then IMP CVAGEN6n was used to 
conduct Landmark data for canonical variate analysis [28] also group membership information was calculated to compare of the populations. Barlett's test and Goodll's F test were applied by the software IMP TwoMorphGen6 [28].

The size morphometry and centroid sizes of the wings were evaluated by one-way ANOVA [29]. The square root of the sum of the variances of landmarks about that centroid in $\mathrm{x}$ - and $\mathrm{y}$ - direction refers to centroid size [16]. The differences calculated accordingly were illustrated with graphs (Minitab v13.2).

The principal components were used to obtain an UPGMA dendrogram. Euclid distance was calculated and then it was used for pooled interval data obtained from the similarity matrix. Procrustes distances were computed by tpsSMALL [17,23] and visualized according to the UPGMA (Unweighted Pairs Group Method Analysis) dendrogram by Ntsys-Pc2.1 $[17,23]$.

\section{Results}

Changeability of shape space was assessed using original coordinates that was conducted for the digitized 18 landmarks. Results of PC analysis (PCA) of the first two relative warps were depicted as a plot (data not shown). The first two PC explained subsequently $14.06 \%$ and $11.74 \%$ of the variance $(25.80 \%$ of the total variance). Principal component analyses suggested no differences in the relative position of the landmarks. There is no deformation at the base of the wing.

Out of the five, two statistically significant canonical vectors with eigenvalues were extracted from the matrix. Axis 1 Lambda 0.8488, X2 = 136.7987, $\mathrm{df}=81, \mathrm{p}<0.0001$; Axis 2 Lambda=0.9109, $\mathrm{X} 2=77.8483, \mathrm{df}=52, \mathrm{p}<0.01$. The CVA based on the shape of front wings showed that there was more overlapping among honey bee populations and no clear groups patterns could be identified except Southeastern. Population. The clusters plotted on CVA graph relatively close each other, and no clear intergaps between groups. Although Southeastern part of Turkey was well separated by two axis. The Aegean and Marmara population were placed mainly in the upper half of the plot. Thrace population mainly in lower-right-hand quadrant and small set of samples from Southeastern in more lower-left hand of the plot (Fig 4).

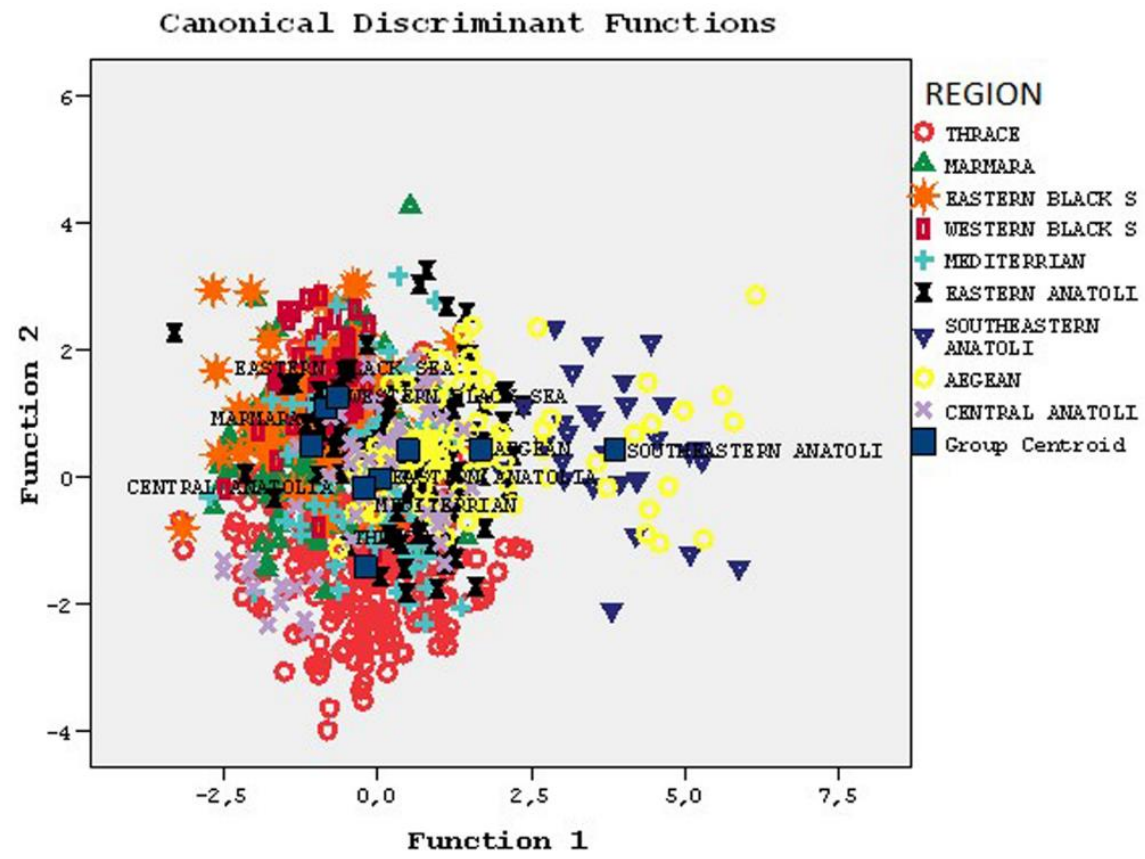

Figure 4. Two-dimensional clustering in Canonical Variates Analysis of individuals' data from 9 different geographic regions

UPGMA dendrogram based on euclidean distance showed higher resolution among the populations. In the UPGMA dendrogram Southeastern honey bee populations were clustered separately and remained as distinct units within this phenogram. Thrace population is coherent groups discriminated from the rest ones. Aegean and Marmara samples clustered very closely. Mediterranean and East Anatolian were overlapped and made up a larger cluster with Central Anatolia Eastern Black Sea and western Black sea samples (Fig 5). 


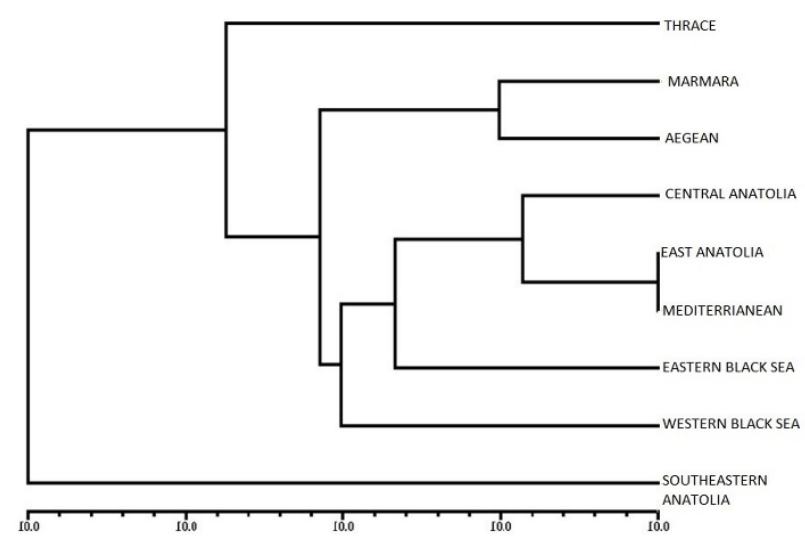

Figure 5. Phylogenetic tree according UPGMA (Un-weighed Pair Group Method) method based on standardized Euclidean distance.

Oneway ANOVA was conducted to test the centroid size differences. Single classification of ANOVA showed a significant difference of centroid size $(F=16.61, p<0.0001)$ among honey bee populations (Fig 6). Out of the Thrace population, generally all honey bee populations showed the expected classification schema by means of their centroid sizes. There were significant size differences between Southeastern and Thrace regions. Honey bees from central Anatolia and Eastern Anatolian Region were not different significantly from each other.

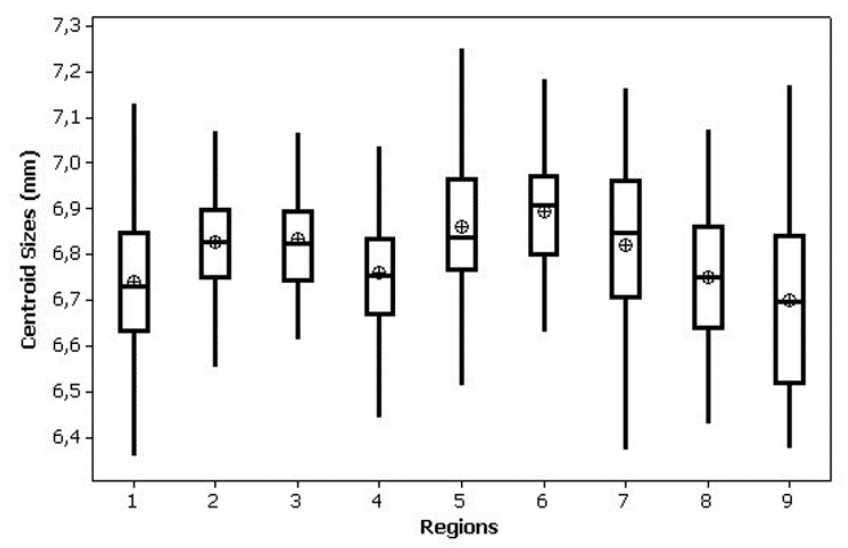

Figure 6. Plot of the centroid size in honey bee populations from nine different regions. (From the data of centroid size from the wings. Group means are indicated by lines and dot plots). Location codes; 1-Thrace, 2-Marmara, 3-Central Anatolia, 4-Aegean, 5-Western Black Sea, 6-Eastern Black Sea, 7-East Anatolia, 8-Mediterrianean, 9-Southeastern Anatolia

\section{Conclusions and discussion}

In the present study, geometric morphometric method has been used as a tool to investigate relationship of honey bees in Turkey. Geometric morphometric is relatively provide explicit results in many fields of morphometry $[11,12,13,15,18,20,21]$.

In our previous traditional morphometric study [30,14] with the current regional populations, the linear regressions were found between wing size and geographical locations (longitude and latitude). The present analysis enables comparisons of size independent covariates in wing shape because landmark coordinates of each specimens were normalized by centroid size.

According to Principal Component Analysis (PCA) and Canonical Variate Analysis (CVA), plot depicted based on PC1 and PC2 showed that no significant shape variation among honey bee populations in Turkey. On contrast to PCA, results of CVA analysis revealed strong two main cluster (Southeastern Anatolia, and the rest ones). According to researchers A.m. syriaca have been distributing in Hatay-Antakya province in South part of the Turkey which is the border line to Syria [4, 14, 36,37]. Because of this border line honey bee samples in this study also shown distinctions. Reduction of dimensionality of variability by conducting a CVA would be appropriate to explore shape variability within homogenous samples such as subspecies [31,32]. Other studies with different species and subspecies came on also the same conclusion: Relative warp is a useful tool for distinguish more distinct species [12,13,33].

Geometric morphometric technique can extract subtle differences when compared to the traditional morphometric. In the previous study based on traditional morphometric analysis with these current samples of 
southeastern population (A. m. meda) formed strong close cluster with honey bees (A. m. anatoliaca) from Mediterranean and Central Anatolia [30]. However, in this study, the small set of specimen belong to Southeastern Anatolian populations were further resolved and formed a distinct cluster that may be belong to meda1 in group 2 sensu Arias and Shapperd [34] or belong to fourth new mtDNA lineage (O-), A. m. syriaca Franck, et al., [2]; or intermediate group.

It was reported that there were three different subspecies, A. m. meda, A. m. anatoliaca and A. m. syriaca, in the southeastern part of Turkey [4,5,9,10,35] Kandemir [9,35]. However, some unanswered questions with Ruttner's [4] and Kekeçoğlu's [14] were remained: Is there direct contact with the A. $m$. syriaca or are there intermediate. How far to the east, A. m. syriaca extend and is there any borderline to the population of A. m. meda in South Eastern Anatolia. Kandemir, et al. [35] claimed that fourth new lineage have been in only Hatay city in the southeastern part of Turkey. In the present study it is proposed that fourth new lineage not only have been in Hatay, also may extends to further eastern drawn included Urfa, or there was hybrid zone where comprise A. m. meda, syriaca and anatoliaca. This information obtained using new method reveal specific patterns of honey bee biodiversity that cannot be readily discerned by more traditional morphometric methods. There were needed to detailed studies to explain current taxonomic status of these honey bees and population diversity on southeastern part of Turkey.

Honey bees of the Western part of Turkey seemed like a separate group. But on account of its closeness to the general anatoliaca cluster, it was reported as a local population of A. m. anatoliaca [4]. The previous research results of the traditional morphometric study [30] and the results of the current study agree with Ruttners' [4] findings. Honey bees taken from Thrace slightly resolved from both central Anatolia and western part (Marmara and Aegean regions) of Turkey. This current result based on geometric morphometric, disagree with the opinion that Thracian honey bee populations may belong to A. m. carnica ecotype in lineage C. However, there is also opposite views on methodologies, such as Smith, et al. [5] on mtDNA, Kandemir, et al. [7,8] on alloenzyme and morphometric, Bodur, et al. [6] on microsatellite.

It is interesting that there was no more compatibility between results from the current geometric morphometric and previous mtDNA studies. To clarify this incomprehensible difference there should be more specific researches which compare mtDNA and morphometry of Sout Easthern Anatolia honey bees.

Modern geometric morphometric can be immensely powerful in exploring phylogenetic relationships and discrimination of populations combining with other approaches, molecular (microsatellite) and mtDNA analysis. The present accurate description of honey bees' variability offers an important basis for future comparative research with neighboring population (from Iran, Iraq, and Syria) to better clarify the origin and characteristics of southeastern population of Turkey.

There are intensive migratory beekeeping and commercial queen bee activities in the beekeeping sector. As long as these activities continue, it will be inevitable that the Anatolian honey bee biodiversity will enter the process of extinction [14,37]. For this reason, the genetic and morphometric differences of honey bee races and ecotypes in Anatolia should be defined and studies to protect the biodiversity of the Anatolian honey bee must be started urgently. Therefore, detailed biodiversity studies conducted with different methods are extremely important in terms of protecting local gene resources.

\section{References}

[1] Garnery, L., Franck, P., Franck, P., Vautrin, D., \& Solignac, M. (1998). European honey bee (Apis mellifera mellifera). Genetics Selection Evolution. 30(1), 49-74. https://doi.org/10.1186/1297-9686-30-S1-S49

[2] Franck, P., Garnery L., Solignac M. \& Cornuet J.M. (2000) Molecular confirmation of a fourth lineage in honey bees from the Near East. Apidologie, 31(2):167-180. doi: 10.1051/apido:2000114ff. ffhal-00891704f

[3] Bodenheimer, F.S. (1941) Studies on the honey bee and beekeeping in Turkey. Merkez Ziraat Mücadela Enstitüsü, Ankara.

[4] Ruttner, F. (1988) Biogeography and taxonomy of honey bees. Springer Verlag, Berlin, $298 \mathrm{pp}$

[5] Smith, D., Slaymaker A., Palmer M. \& Kaftanoglu O. (1997) Turkish honey bees belong to the east Mediterranean mitochondrial lineage, Apidologie 28: 269-274. doi: 10.1051/apido:19970503

[6] Bodur, Ç., Kence M. \& Kence A. (2007) Genetic structure of honey bee, Apis mellifera L. (Hymenoptera: Apidae) populations of Turkey inferred from microsatellite analysis. Journal of Apicultural Research. 46(1): 50-56. doi: 10.1080/00218839.2007.11101366

[7] Kandemir, I., Kence M. \& Kence A. (2000) Genetic and morphometric variation in honey bee (Apis mellifera) population of Turkey. Apidologie, 31(3): 343-356. doi: 10.1051/apido:2000126f

[8] Kandemir, I., Kence M. \& Kence A. (2005) Morphometric and electrophoretic variation in different honey bees (Apis mellifera) population. Turkish Journal of Veterinary \& Animal Sciences, 29: 885-890. http://journals.tubitak.gov.tr/veterinary/abstract.htm?id=7728 
[9] Kandemir, I., Kence M., Sheppard W.S. \& Kence A. (2006a) Mitochondrial DNA variation in honey bee (Apis mellifera L.) population from Turkey, Journal of Apicultural Research and Bee World, 45(1): 33-38. doi: https://doi.org/10.1080/00218839.2006.11101310

[10] Palmer, M.N., Smith D.R. \& Kaftanoglu O. (2000) Turkish Honey bees: Genetic variation and evidence for a fourth lineage of Apis mellifera mtDNA. The Journal of Heredity, 91(1): 42-46. doi: 10.1093/jhered/91.1.42.

[11] Oleksa, A. \& Tofilski, A. (2015). Wing geometric morphometrics and microsatellite analysis provide similar discrimination of honey bee subspecies. Apidologie, 46:49-60. doi: 10.1007/s13592-014-0300-7.

[12] Kambur, M. \& Kekeçoğlu, M. (2018a). The loss of genetic diversity on native Turkish honey bee (Apis mellifera L.) subspecies. Anadolu Journal of Agricultural Sciences, 33, 73-84. doi: 10.7161/omuanajas.337798.

[13] Kambur, M. \& Kekeçoğlu, M. (2018b). The current situation of Turkey honey bee (Apis mellifera L.) biodiversity and conservations studies. Biological Diversity and Conservation, 11(1): 105-119. doi: 10.13140/RG.2.2.12203.54568

[14] Kekeçoğlu, M. (2018). Morphometric divergence of anatolian honey bees through loss of original traits: A dangerous outcome of Turkish apiculture. Sociobiology, 65(2): 232-243. doi: 10.13102/sociobiology.v65i2.1895.

[15] Nawrocka, A., Kandemir, İ. Fuchs, S. \& Tofilski, A. (2018). Computer software for identification of honey bee subspecies and evolutionary lineages. Apidologie, 49:172-184. doi: 10.1007/s13592-017-0538-y.

[16] Bookstein, F.L. (1991) Morphometric tools for landmark data - Geometry and Biology. Cambridge University Press.

[17] Rohlf, F.J. (2000a). Statistical power comparisons among alternative morphometric methods. American Journal of Physical Anthropology. 111:463-478. doi: https://doi.org/10.1002/(SICI)10968644(200004)111:4<463::AID-AJPA3>3.0.CO;2-B

[18] Kambur, M. (2017). Türkiye bal arısı (Apis mellifera L.) biyoçeşitliliğinin geometrik morfometrik yöntemler ile belirlenmesi. Yüksek Lisans Tezi. Düzce Üniversitesi, Fen Bilimleri Enstitüsü, 108s, Düzce.

[19] Tofilski, A. (2008). Using geometric morphometrics and standard morphometry to discriminate three honey bee subspecies. Apidologie, 39(5):558-563. doi: 10.1051/apido:2008037

[20] Francoy, T.M., Silva R.A.O., Nunes-Silva P., Menezes C. \& Imperatriz-Fonseca V.L. (2009a). Gender Identification of five genera of stingless bees (Apidae, Meliponini) based on wing morphology. Genetics and molecular research, 8(1): 207-214. doi: 10.4238/vol8-1gmr557

[21] Francoy, T.M., Wittmann D., Steinhage V., Drauschke M., Müller S., Cunha D.R., Nascimento A.M., Figueiredo V.L.C., Simoes Z.L.P., DeJong D., Arias M.C. \& Gonçalves L.S. (2009b). Morphometric and Genetic changes in a population of Apis mellifera after 34 years of Africanization, Genetic and Molecular Research, 8 (2): 709-717.

[22] Hatjina, F., Haristos L. \& Bouga M. (2004). Geometric morphometrics analysis of honey bee populations from Greek Mainland, Ionian Islands and Crete island. Proceedings of the First European Conference of Apidology, Udine, Italy pp.44.

[23] Rohlf, F.J. (2000b) Geometric morphometrics and phylogeny, Department of Ecology and Evolution, State University of New York, Stony Brook, NY, USA.

[24] Rohlf, F.J. (2006). Department of Ecology and Evolution, State University of NewYork at Stony Brook.

[25] Slice, D. E. (2001). Landmark configurations aligned by Procrustes analysis do not lie in Kendall's shape space. Systematic Biology, 50 (1): 141-149.

[26] Rohlf, F.J. (1999) On the use of shape spaces to compare morphometric methods. Hystrix. 11(1): 1-17. doi: https://doi.org/10.4404/hystrix-11.1-4134

[27] Alibert, P., Moureau B., Dommergues J.L. \& David B. (2001) Differentiation at a micro geographical scale within two species of ground beetle, Carabus auronitens and C. nemoralis (Coleoptera, Carabidae): a geometrical morphometric approach. Zoologica Scripta. 30(4): 299-316. doi: https://doi.org/10.1046/j.14636409.2001.00068.x

[28] Zelditch, M.L., Swiderski D.L., Sheets H.D. \& Fink W.L. (2004). Geometric morphometrics for biologists. Elsevier/Academic Press. London. 443 pp.

[29] Sokal, R.R. \& Rohlf F.J. (1995) Biometry. The principles and practice of statistics in biological research. 3rd ed.W.H. Freeman and Company, New York, pp 887. 
[30] Kekeçoğlu M., Soysal M.İ. (2010). Genetic Diversity of Bee Ecotypes in Turkey and Evidence for Geographical Differences Romanian Biotechnological Letter. Romanian Biotechnological Letters, 15(5), 5646-5653.

[31] Rohlf, F.J. \& Loy A., Corti M. (1996). Morphometric analysis of Old World Talpidae (Mammalia, Insectivora) using partial-warp scores. Systematic Biology, 45(3): 344-362.

[32] Adams, D.C. \& Funk D.J. (1997) Morphometric inferences on sibling species and sexual dimorphism in Neochlamisus bebbianae leaf beetles: multivariate applications of the thin-plat spline. Systematic Biology, 46:180-194. doi: https://doi.org/10.1093/sysbio\%2F46.1.180

[33] Aytekin, M.A., Terzo M., Rasmont, P. \& Çağatay N. (2007) Landmark based geometric morphometric analysis of wing shape in Sibirocobombus Vogt (Hymenoptera: Apidae: Bombus Latreille). Annales De La Societe Entomologique De France. 43 (1): 95-102. doi: https://doi.org/10.1080/00379271.2007.10697499

[34] Arias, M.C. \& Sheppard W.S. (1996) Molecular phylogenetics of honey bee subspecies (Apis mellifera L) inferred from mitochondrial DNA sequence. Molecular Phylogenetics and Evolution. 5(3): 557-566. doi: https://doi.org/10.1006/mpev.1996.0050

[35] Kandemir, I., Pinto M.A., Meixner M.D. \& Sheppard Ws. (2006) Hinf-I digestion of cytocrome oxidase I region is not a diagnostic test for A. m. lamarckii. Genetics and Molecular Biology, 29(4): 747-749. doi: https://doi.org/10.1590/S1415-47572006000400027

[36] Özbakır, G.Ö. (2011) "Türkiye'nin Güneydoğu Sınırboyu Bal Arısı Populasyonlarının (Apis Mellifera L.) Morfolojik Özellikleri," Doktora tezi, Zootekni Bölümü, Ankara Üniversitesi, Ankara, Türkiye.

[37] Kambur Acar, M., \& Kekeçoğlu. M. (2020). Is The Natural Honey Bee Biodiversity of Anatolia in the Process of Extinction?. Yüzüncü Y1l Üniversitesi Tarım Bilimleri Dergisi, 30(3), 593-600. 